Primljen / Received: 23.8.2016. Ispravljen / Corrected: 21.8.2017.

Prihvaćen / Accepted: 22.9.2017. Dostupno online / Available online: 10.4.2018.

\section{Experimental modal investigation of scaled minaret embedded in different soil types}

Authors:

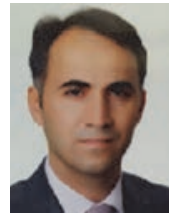

${ }^{1}$ Assoc.Prof. Kemal Hacıefendioğlu, PhD. CE kemalheo@gmail.com

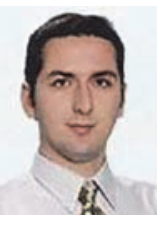

${ }^{2}$ Emre Alpaslan, PhD. CE emre.alpaslan@omu.edu.tr

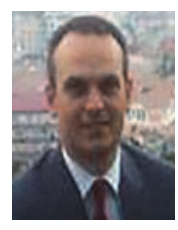

${ }^{2}$ Assist.Prof. Gökhan Demir, PhD. CE gokhan.demir@omu.edu.tr

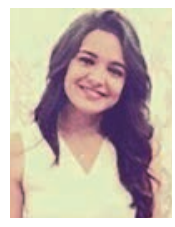

${ }^{2}$ Burcu Dinç, MSc. CE burcu.dinc@omu.edu.tr

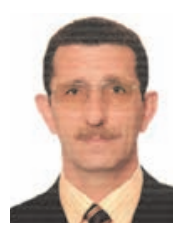

${ }^{2}$ Assist.Prof. Fahri Birinci, PhD. CE fbirinci@omu.edu.tr

${ }^{1}$ Private sektor, Turkey

¿University Ondokuz Mayıs, Turkey

Faculty of Civil Engineering
Scientific Paper - Preliminary report Kemal Hacıefendioğlu,Emre Alpaslan, Gökhan Demir, Burcu Dinç, Fahri Birinci

Experimental modal investigation of scaled minaret embedded in different soil types

The influence of various types of foundation soil on dynamic behaviour of reinforcedconcrete minarets is analysed in the paper. A 1:20 RC scale model was constructed in laboratory for the testing. The gravel, sand, and clay-gravel mixture, were used as foundation soil types to determine differences in dynamic behaviour as related to the type of foundation soil. Experimental measurements were conducted using the Operational Modal Analysis (OMA), taking into account ambient vibrations due to wind action and traffic. Test results show that the dynamic behaviour of RC minaret is strongly influenced by the type of foundation soil.

Key words:

operational modal analysis, RC minaret, enhanced frequency domain decomposition, ambient vibrations

Prethodno priopćenje

Kemal Hacıefendioğlu,Emre Alpaslan, Gökhan Demir, Burcu Dinç, Fahri Birinci

Eksperimentalno modalno istraživanje modela minareta u raznim vrstama temeljnog tla

U radu se prikazuje analiza utjecaja raznih vrsta temeljnog tla na dinamično ponašanje armiranobetonskih minareta. Za potrebe istraživanja u laboratoriju je izrađen ab model u mjerilu 1:20. Kako bi se ustanovile razlike u dinamičkom ponašanju modela minareta ovisno o vrsti temeljnog tla, kao temeljno tlo korišten je šljunak, pijesak i mješavina gline i šljunka. Eksperimentalna mjerenja su provedena pomoću operacionalne modalne analize (OMA), pri čemu su u obzir uzete okolne vibracije uslijed djelovanja vjetra i prometa. Rezultati ispitivanja pokazuju da vrsta temeljnog tla bitno utječe na dinamičko ponašanje ab minareta.

Ključne riječi:

operacionalna modalna analiza, ab minaret, poboljšana dekompozicija frekventnog područja, ambijentalne vibracije

Vorherige Mitteilung

Kemal Hacıefendioğlu,Emre Alpaslan, Gökhan Demir, Burcu Dinç, Fahri Birinci

Experimentelle modale Untersuchung der Minarettmodelle auf verschiedenen Baugrundarten

In der Abhandlung wird die Analyse des Einflusses verschiedener Baugrundarten auf das dynamische Verhalten von Minaretten aus Stahlbeton dargestellt. Zum Zweck der Untersuchung im Labor wurde ein Stahlbetonmodell in einem Maßstab von 1:20 angefertigt. Um den Unterschied im dynamischen Verhalten des Minarettmodells abhängig von der Baugrundart festzustellen, wurde als Baugrund Kies, Sand und eine Mischung von Ton und Kies verwendet. Die experimentellen Messungen wurden mithilfe der operationalen Modalanalyse (OMA) durchgeführt, wobei die durch Wind und Verkehr verursachte Umgebungsvibration berücksichtigt wurde. Die Untersuchungsergebnisse zeigen, dass die Baugrundart das dynamisch Verhalten der Minarette aus Stahlbeton erheblich beeinflusst.

Schlüsselwörter:

operationale Modalanalyse, Minarett aus Stahlbeton, verbesserte Dekomposition des Frequenzbereichs, Umgebungsvibration 


\section{Introduction}

Dynamic behaviour of an existing structure depends on both its material properties and the type of boundary conditions at the foundation level. Structural response, involving also the foundations of the structure, is called the soil-structure interaction. The soil-structure interaction has to be considered so as to accurately understand dynamic characteristics of an existing structure. It is clear that the structures founded in a deformable soil exhibit a dynamic response that differs significantly from that of structures founded in a rigid soil. The soil-structure interaction exerts a considerable influence on fundamental natural frequencies of structures and it especially reduces for the second and higher modes. Furthermore, damping ratios of structures are affected considerably by considering the soil-structure interaction, especially for structures that have a lower number of storeys, larger foundations, and are embedded in softer soils [1].

Minarets are tall and slender towers sometimes reaching up to $70 \mathrm{~m}$ in height. They are built at the side of a mosque and feature stone or brick materials and reinforced stairs. The reinforced concrete minarets have frequently been built in the earthquake-affected regions in Turkey. So, minarets built in these regions might be exposed to earthquake effects, and these effects might result in the loss of property, collapse and many casualties.

Following collapse of some minarets such as Bodurga [2], Centre [3] and Kadıköy [4] minarets in Çankırı, Bingöl and Sultandağlı, respectively, and some other similar minaret collapse events in Turkey [5], researchers have investigated dynamic behaviour of such structures using both experimental and analytical methods. The experimental modal analysis (EMA) and operational modal analysis techniques (OMA) are used to evaluate dynamic parameters of structures, such as the mode shapes, modal frequencies, and damping ratios. In the EMA, the known input force (impulse hammer, drop weight, or electrodynamics shaker) is applied to structures to determine their modal properties. The OMA is used to identify modal properties of structures by collecting vibrational signals when the structure is in operating condition. In this method, the structure can be under a variety of unmeasured excitation sources such as loads caused by wind, traffic, waves, etc. Due to cost concerns and possible damage to structures when the EMA is applied, the OMA has become a generally more attractive in the realisation of studies as it ranks among non-destructive testing techniques. The OMA exhibits some techniques based on the frequency and time domain. These techniques are used to obtain dynamic parameters of structures. The Stochastic Subspace Identification (SSI), Poly reference Complex Exponential, Eigen system Realization Algorithm, and Ibrahim Time Domain techniques, are in time domain, and the Enhanced Frequency Domain Decomposition (EFDD) and Frequency Domain Subspace Techniques are in frequency domain [6-11].

The available literature presents numerous research topics related to application of non-destructive testing techniques,
OMA techniques in particular, on various types of civil engineering structures, such as bridges [12-17], dams [18], full-scale buildings [19-22], silos [23], and nuclear power plants [24]. A notable example is the study of dynamic structural parameters obtained by full-scale ambient vibration testing of an approximately $74 \mathrm{~m}$ high tower dating back to the $17^{\text {th }}$ century, characterized by the presence of major cracks on the western and eastern load-bearing walls [25]. Another study is related to dynamic identification of a masonry bell tower revealing a highly damaged condition and, consequently, a high vulnerability to dynamic and seismic forces. The study presents experimental investigations and operational modal analysis results aimed at defining the finite element model of this historic structure. It was concluded that a significant effort is needed to define a reasonable finite element model that could be compatible with the obtained experimental dynamical properties [26]. The dynamic analysis and seismic performance of reinforced concrete minarets were also the subject of various studies presented in the literature. Probable cause of extensive damage to a reinforced concrete minaret was examined by gaining proper understanding about the observed failure modes and their seismic performance, and through dynamic analysis of the minaret [27]. Another damage assessment study was performed by using the wavelet packet transform (WPT) and the artificial neural network (ANN). The results of the study show that the method used in the study is computationally efficient and sufficient to understand the existence of damage patterns [28]. To understand dynamic behaviour of historical unreinforced masonry minarets, three historical unreinforced masonry minarets, 20, 25, and $30 \mathrm{~m}$ in height, were modelled and analysed using two ground motions recorded in Turkey during the 1999 Kocaeli and Duzce earthquakes. The modal analysis results revealed that the minaret height and spectral characteristics of the input motion were affected by structural periods and the overall structural response [29]. A study dealt with minimizing signal noise that affects reliability and accuracy of the data by utilizing a discrete wavelet transform (DWT) approach. The results of the study show that even if the signals are characterized by heavy or light noise, the proposed method still exhibits better performance compared to traditional methods [30]. An analytical and operational modal analysis of a Turkish style reinforced concrete minaret was conducted and natural frequencies and damping ratios of the minaret were identified by using the peak picking (PP) and stochastic subspace identification (SSI) methods [31]. The finite element model, modal testing, finite element model updating, and earthquake behaviour before and after model updating, were investigated for a Turkish style reinforced concrete minaret. Modal parameters of the minaret were obtained under natural excitations, such as wind action and human activity [32]. The ambient vibration method was used to build a base slab for different ground conditions. In this study, the base slab was modelled so as to be 20 times smaller compared to the actual building base. Dynamic characteristics of a $150 \times 100 \times 5 \mathrm{~cm}$ 
reduced scale base slab model were investigated and the study concluded that natural frequencies, mode shapes, and modal damping ratios of the structure, are importantly affected by ground conditions [33].

Most studies presented in the literature focus on investigation of modal parameters of minarets; however, the effects of different soil types on dynamic characteristics of minarets have not been evaluated. Therefore, this study is conducted to define dynamic characteristics of a reinforced concrete minaret model constructed in laboratory conditions and embedded in three different soil types. In order to understand the effect of soil types on the dynamic behaviour of the reinforced concrete minaret, the first three modal parameters are identified from modal testing, and the results are compared to each particular case.

\section{Modal test analysis}

Ambient vibration tests can be quite an efficient method to estimate elastic characteristics and modal parameters (natural frequencies, modal damping ratios, and mode shapes) of the soil-structure interaction of structures subjected to environmental loads. Natural frequencies and natural mode shapes are one of the most significant key parameters of any structure due to its direct relation to the stiffness of structures. Therefore, the changes in natural frequencies and mode shapes of structures can give an indication on the existence of damage. The Operational Modal Analysis (OMA) deals only with output measurements of structural systems, without artificial excitation. The Enhanced Frequency Decomposition Domain (EFDD) and Stochastic Subspace Identification (SSI) are two methods that are commonly used to characterize modal parameters of structures.

\subsection{Soil-structure interaction effects on modal parameters}

The SSI analysis widely relies on single-degree-of freedom structural models in that the inertial interaction effects are notified in the first mode. This system can be investigated as a direct model of a single story building, or more generally, as an approximate model of a multi-mode, multi-story structure that is dominated by the first-mode response [34].

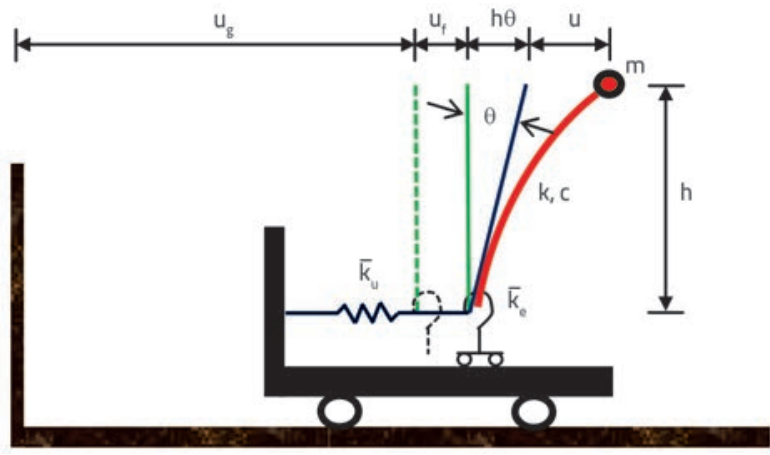

Figure 1. Simplified model for analysis of inertial interaction [34]
Equations of motion defining the simple system (Figure 1) are: Lateral at:

$m\left(\ddot{u}_{f}+h \ddot{\theta}+\ddot{u}\right)+c \dot{u}+k u=-m \ddot{u}_{g}$

Total lateral:

$m\left(\ddot{u}_{f}+h \ddot{\theta}+\ddot{u}\right)+m_{f} \ddot{u}_{f}+c_{u} \dot{u}_{f}+k_{u} u_{f}=-\left(m+m_{f}\right) \ddot{u}_{g}$

Total rotation:

$m h\left(\ddot{u}_{f}+h \ddot{\theta}+\ddot{u}\right)+\mathrm{I} \ddot{\theta}+c_{\theta} \dot{\theta}+k_{\theta} \theta=-m h \ddot{u}_{g}$

where $m, k$ and care the mass, stiffness and damping matrices, respectively, $u, \dot{u}$ and $\ddot{u}$ are the displacement, velocity and acceleration vectors, respectively, his the height of the structure and lis the rotational moment of inertia of the structure. $k_{u^{\prime}} c_{u^{\prime}}$ $k_{\theta}$ and $c_{\theta}$ are coefficients of the foundation impedance function stating the stiffness and damping characteristics of the soil/ foundation interaction. As related to Figure 1, the impedance function is identified as

$\bar{k}_{k}=k_{k}\left(\alpha_{0}, v\right)+i \omega c_{k}\left(\alpha_{0}, v\right)$

where the subscript $k$ symbolizes either deformation mode $u$ or $\theta, \omega$ is the angular frequency (rad/sec), $\alpha_{0}$ is the dimensionless frequency identified by $\alpha_{0}=\omega r / V_{s^{\prime}} r$ is the foundation radius, $V_{s}$ is the soil shear wave velocity, and $v$ is the soil Poisson ratio.

The time-dependent motions in Eq. (1), (2) and (3) are converted to the Laplace domain according tof $(t)=\hat{f} e^{s t}$ . As shown previously, the coefficients $k_{u^{\prime}} c_{u^{\prime}} k_{\theta}$ and $c_{\theta}$ are realvalued functions of frequency. In the Laplace domain, they are commented as real-values estimated at the pole of the transfer function being sought. For practical purposes, these Laplace domain coefficients are the same as the foundation impedance in the frequency domain estimated at the frequency of the structure for the favourable level of hysteretic soil damping. Converting to the Laplace domain and splitting through by the mass coefficients, Eq. (1), (2) and (3) can be re-written as

$$
\begin{aligned}
& s^{2} \hat{u}_{f}+s^{2} h \hat{\theta}+A \hat{u}=-s^{2} \hat{u}_{g} \\
& A_{u} \hat{u}_{f}+s^{2} \mu h \hat{\theta}+s^{2} \mu \hat{u}=-s^{2} \hat{u}_{g} \\
& s^{2} \hat{u}_{f}+A_{\theta} h \hat{\theta}+s^{2} \hat{u}=-s^{2} \hat{u}_{g}
\end{aligned}
$$

where $s$ is the complex-valued Laplace domain variable and $\mu=$ $\mathrm{m} /\left(\mathrm{m}+\mathrm{m}_{\mathrm{f}}\right)$. Ignoring the rotational inertia of the structure and the mass of the foundation (ie. $I=0, \mu=1$ ) the $A$ coefficients are identified as:

$A_{k}=s^{2}+2 \xi_{k} \omega_{k} s+\omega_{k}^{2}$

where $\omega$ is the angular frequency (rad/sec), $\xi$ is the damping ratio, $\mathrm{k}=[], u$, or $\theta$ (referencing to the fixed-base structure, foundation translation, and foundation rocking, respectively), and the frequencies and damping ratios $\left(\omega_{k^{\prime}} \xi_{k}\right)$ identify the 
dynamic behaviour of the structure $(\omega, \xi)$ or soil-foundation system $\left(\omega_{u^{\prime}} \xi_{u}\right.$ and $\left.\omega_{\theta^{\prime}} \xi_{\theta}\right)$. These parameters depend on the system properties as follows:

$\omega_{k}^{2}=\frac{k_{k}}{m}, \quad \xi_{k}=\frac{c_{k}}{2 m \omega_{k}} \quad(k=[]$ ili u $)$

$\omega_{\theta}^{2}=\frac{k_{\theta}}{m}, \quad \xi_{\theta}=\frac{c_{\theta}}{2 m h^{2} \omega_{\theta}}$

Three unknown response functions $\left(\hat{u}, \hat{u}_{f}, \hat{\theta}\right)$ and three equations are included in Eq. (5), (6), and (7). The response can be obtained directly in terms of system properties [34],

$\frac{\hat{u}}{\hat{u}_{g}}=-\frac{B_{\theta} B_{u} s^{2}}{C_{s}}, \frac{\hat{u}_{f}}{\hat{u}_{g}}=-\frac{B_{\theta} B s^{2}}{C_{s}} ; \frac{h \hat{\theta}}{\hat{u}_{g}}=-\frac{B B_{u} s^{2}}{C_{s}}$

where:

$B_{k}=A_{k}-s^{2}$

$C_{s}=s^{2}\left(B_{u} B+B_{u} B_{\theta}+B_{\theta} B\right)+B_{u} B B_{\theta}$

Eq. (11) is the complete solution for the SSI model in Figure 1. Therefore, any transfer function of interest can be directly determined from these results [34]. The above procedure is applicable to circular foundations, and it has been adapted for rectangular foundation considering the ratio, $B / L$, where $B$ and $L$ are the half-width and half-length of the foundation, respectively. More information can be found in relevant literature [35].

\subsection{Enhanced Frequency Domain Decomposition (EFDD) method}

The Frequency Domain Decomposition (FDD) method is generally used for the Operational Modal Analysis in civil engineering industries. The spectral density matrix is classified into a set of single degree of freedom (SDOF) systems performing the Singular Value Decomposition within this technique. If the load is white noise, the structure is lightly damped, and the mode shapes of close modes are geometrically orthogonal, then exact results can be obtained using this method. It is possible to get significantly reasonable results even in the case when these assumptions are not satisfied [36]. The EFDD technique is an improved version of the FDD technique that estimates modal parameters directly from signal processing calculations. In the EFDD technique, the frequency content of the response is obtained by using auto-cross power spectral density functions of the measured time series of responses [36]. The original EFDD method is presented in several papers [37].

The relationship between the unknown input and measured output signals in the EFDD technique can be expressed as follows [38].

$G_{y y}(j \omega)=H(j \omega)^{*} G_{x x}(j \omega) H(j \omega)^{T}$ where $G_{x x}(j \omega)$ is the $r x r$ Power Spectral Density (PSD) matrix of the input signal, $r$ is the number of inputs, $G_{y y}(j \omega)$ is the $m x m$ PSD matrix of the output signal, $m$ is the number of responses, $H(j \omega)$ is the $m x r$, Frequency Response Function (FRF) matrix, and ${ }^{*}$ and ${ }^{T}$ describe complex conjugate and transpose, respectively. The FRF matrix $H(j \omega)$ is defined a:

$H(j \omega)=\sum_{k=1}^{n} \frac{R_{k}}{j \omega-\lambda_{k}}+\frac{R_{k}^{*}}{j \omega-\lambda_{k}^{*}}$

where $n$ is the mode number, $\lambda_{k}$ is the pole, and $R_{k}$ is the residue matrix. Using Eq. (13) in Eq. (12), the following is obtained [36]:

$G_{y y}(j \omega)=\sum_{k=1}^{n} \sum_{s=1}^{n}\left[\frac{R_{k}}{j \omega-\lambda_{k}}+\frac{R_{k}^{*}}{j \omega-\lambda_{k}^{*}}\right] G_{x x}(j \omega)\left[\frac{R_{s}}{j \omega-\lambda_{s}}+\frac{R_{s}^{*}}{j \omega-\lambda_{s}^{*}}\right]^{\bar{H}}$

where $s$ stands for singular values and $\bar{H}$ is the complex conjugate and transpose. The output PSD can be reduced to a pole/residue form as follows:

$G_{y y}(j \omega)=\sum_{k=1}^{n} \frac{A_{k}}{j \omega-\lambda_{k}}+\frac{A_{k}^{*}}{j \omega-\lambda_{k}^{*}}+\frac{B_{k}}{-j \omega-\lambda_{k}}+\frac{B_{k}^{*}}{-j \omega-\lambda_{k}^{*}}$

where $A_{k}$ and $B_{k}$ are the $\mathrm{k}$-th residue matrices of the output PSD. The following expression is obtained by performing the singular value decomposition of the output PSD matrix known at discrete frequencies $\omega=\omega_{i}$

$G_{y y}\left(j \omega_{i}\right)=U_{i} S_{i} U_{i}^{\bar{H}}$

where matrix $U_{i}$ represents the unitary matrix holding the singular vector $u_{i{ }^{\prime}} S_{i}$ is the diagonal matrix holding the scalar singular values $S_{i j}$. PSD matrix in Eq. (16), peak values and singular vectors, $u_{i j^{\prime}}$ correspond to natural frequencies and natural mode shapes, respectively.

\subsection{Stochastic subspace identification (SSI) method}

In contrast to the FDD technique, the Stochastic Subspace Identification (SSI) technique uses time-domain techniques. Some of the main characteristics of the SSI technique are: direct dealing with raw response time series, data order and deterministic input signal, and noise reduced by orthogonal projection and synthesis from decomposition. The SSI was initially introduced by Van Overschee and De Moor [11] and was subsequently further developed by several authors, including Hermans and Van de Auweraer [39], Peters [40] and Reynder and Roeck [41]. Some benefits of the SSI method are: work in time domain, no leakage due to not using any Fourier transformation, and use of much smaller model orders than other commercially available high order model estimators [42]. In this technique, dynamic parameters of the structure can be expressed by a set of linear, constant coefficients and secondorder differential equations: 
$[M]\{\ddot{U}(t)\}+[C]\{\dot{U}(t)\}+[K]\{U(t)\}=\{R(t)\}=[B](u(t))$

where $[\mathrm{M}],[\mathrm{C}]$ and $[\mathrm{K}]$ are the mass, damping and stiffness matrices, respectively, $\{R(t)\}$ is the excitation force, $\{\ddot{U}(t)\},\{\dot{U}(t)\}$ and $\{U(t)\}$ are acceleration, damping and displacement vectors over continuous time $t$, respectively. Force vector can be described using the matrix $[B]$ defining the inputs in space and a $\operatorname{vector}(u(t))$. By using following definitions [43]:

$x(t)=\left(\begin{array}{c}U(t) \\ \dot{U}(t)\end{array}\right), A_{*}=\left(\begin{array}{cc}0 & I \\ -M^{-1} K & -M^{-1} C\end{array}\right), B_{*}=\left(\begin{array}{c}0 \\ M^{-1} B\end{array}\right)$

Eq. (17) can be written into the state equation:

$\dot{x}(t)=A_{*} x(t)+B_{*} u(t)$

where $A_{\Downarrow}$ is the state matrix, $B$ is the input matrix, and $x(t)$ is the state vector. After some assumptions and mathematical manipulations, the discrete-time purely stochastic state-space model of a vibration structure is obtained as follows:

$x_{\mathrm{k}+1}=A x_{\mathrm{k}}+w_{k}$

$y_{k}=C x_{k}+v_{k}$

Eq. (20) represents the general form of the time-domain system identification through operational vibration measurements. More detailed explanations about obtaining Eq. (20) can be found in literature [41].

\subsection{Modal assurance criterion (MAC)}

The Modal Assurance Criterion (MAC) can be used in the application of modal analysis due to its capability to compare different mode shapes in one number. The MAC value is between 0 and 1. If there is enough agreement between mode shapes, the MAC value is around 1. For two different mode shapes $\left\{\varphi_{A}\right\}$, $\left\{\varphi_{x}\right\}$, the MAC value can be calculated as follows [44]:

$\operatorname{MAC}(r, s)=\frac{\left|\left\{\varphi_{A}\right\}_{r}^{T}\left\{\varphi_{X}\right\}_{s}\right|^{2}}{\left(\left\{\varphi_{A}\right\}_{r}^{T}\left\{\varphi_{A}\right\}_{r}\right)\left(\left\{\varphi_{X}\right\}_{s}^{T}\left\{\varphi_{X}\right\}_{s}\right)}$

where $\left\{\varphi_{\chi}\right\}_{\mathrm{s}}$ is test modal vector, mode $s,\left\{\varphi_{A}\right\}_{r}$ is the compatible modal vector, mode $r$ and $T$ is the transpose.

\section{Experimental setup and scaled reinforced concrete minaret}

In this study, 1:20 reduced scale model of a full-scale reinforced concrete minaret was used to exhibit the effects of soil types on the structural dynamic identification. The quality of concrete used in this model, i.e. C30/37, was determined according to TS EN 206-1 [45]. The ultrasonic testing method was applied. The minaret model was reinforced with fine iron wires. To investigate the vibration mode responses of the target system to the different soil types, the Operational Modal Analysis Method (OMA) was used, and different soil types were placed into the ground, with dimensions being 100
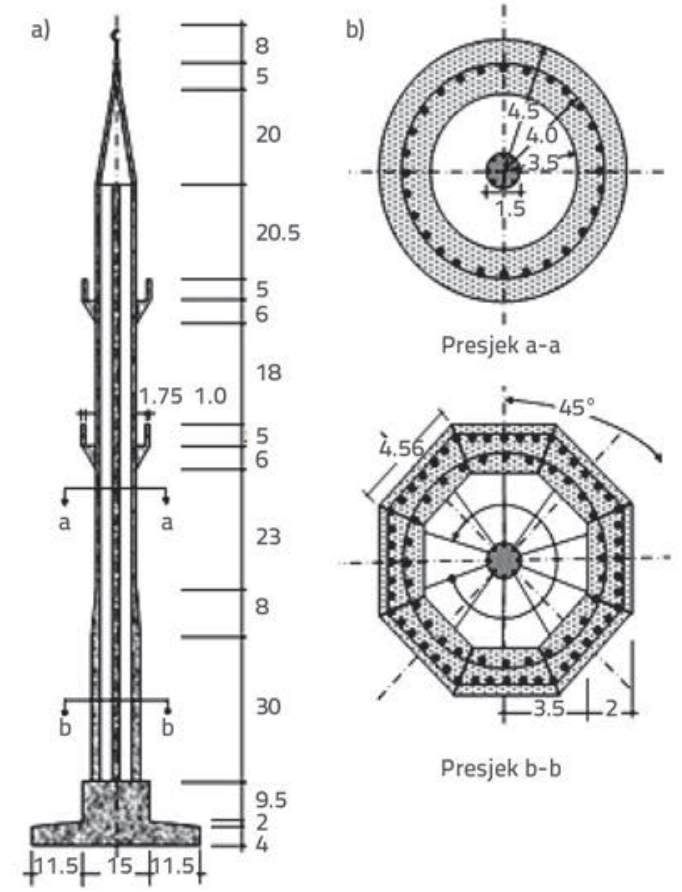

c)

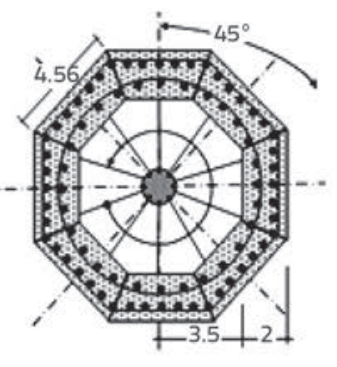

Presjek b-b

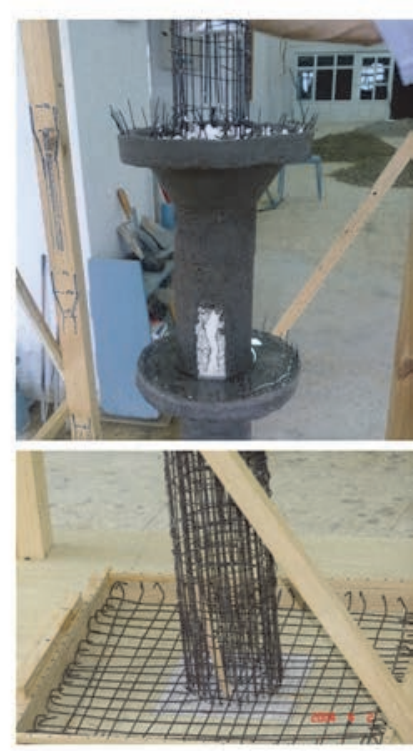

Figure 2. a) Dimensions of 1:20 reduced scale minaret model (cm); b) Minaret model construction procedure

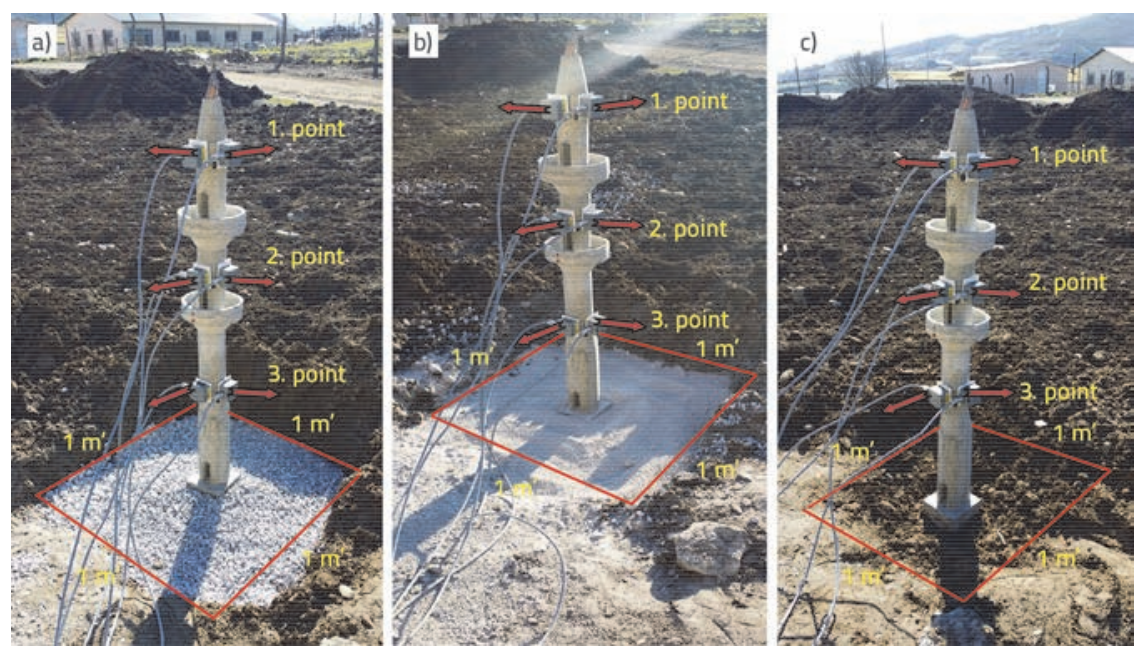

Figure 3. Experimental application of: a) gravel foundation soil type; b) sand foundation soil type; c) clay-gravel mixture foundation soil type 
$x 100 \times 20 \mathrm{~cm}(\mathrm{LxW} x \mathrm{H})$. Dimensions of the scaled model and foundation of the minaret are shown in Figure 1. The scaled model foundation was embedded into different soil types. There was no extra analysis to find the soil type properties used in the study, so the random soil types were used for different foundation soil types. Three cases are taken into account in the analyses to examine the effects of the soil types on the dynamic characteristics of the target structure. The cases given in Figure 2 can be explained as gravel, sand and clay-gravel mixture foundation soil types.

\section{Experimental application}

The OMA method was used to identify modal parameters of the scaled reinforced concrete minaret. The experimental application consisted of the data acquisition system, uniaxial accelerometers, and the control unit (Figure 4). The vibrational response of the structure due to ambient vibrations such as wind and vehicle loads was considered using uniaxial accelerometers. The data acquisition network access software Testlab_V2 was used to gather signals from accelerometers in the $X, Y$ directions from three different locations in total, as shown in Figure 2 . The frequency range and measurement duration was taken as $0-100 \mathrm{~Hz}$ and 15 minutes, respectively. Figure 5 shows the data obtained from the accelerometers.
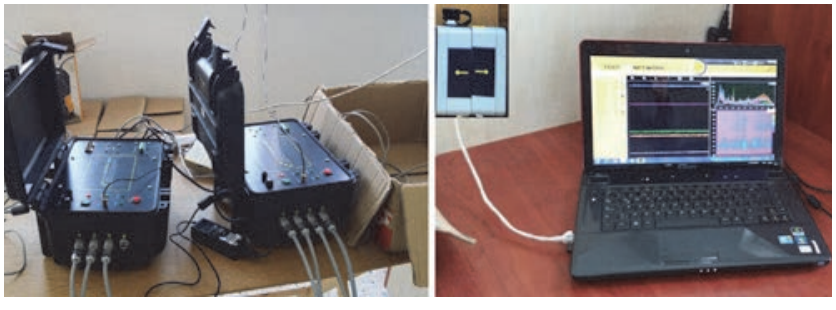

Figure 4. Uniaxial accelerometers, signal conditioner and control unit
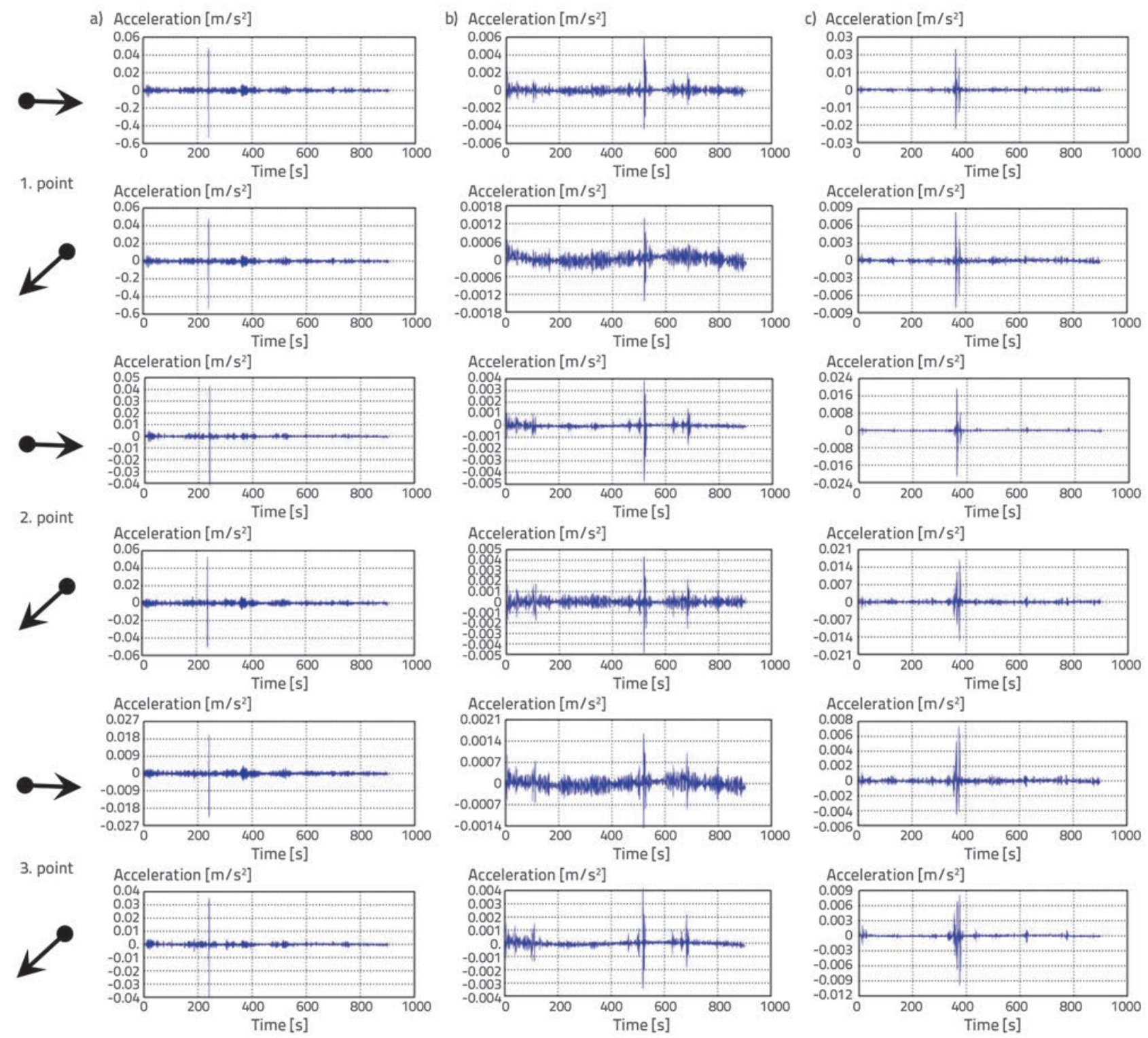

Figure 5. Acceleration time series for channels: a) gravel foundation soil type; b) sand foundation soil type; c) clay-gravel mixture foundation soil type 
The ARTeMIS 1.5 software was utilized to determine experimental modal parameters of the scaled minaret [42]. Natural frequencies, damping ratios, and mode shapes of the minaret, were acquired by means of the EFDD and SSI techniques. The EFDD technique in ARTeMIS identified the single degree of freedom Bell functions, and all modal parameters were estimated from these SDOF Spectral Bells. For the SSI technique, all modal parameters can be exposed by using a specific representation of the transfer function. The Unweighted Principal Component (UPC) algorithm was utilized to analyse the data [46].

\section{Results and discussions}

Modal parameters of the minaret model were obtained according to the ambient vibrational response of the minaret model embedded in gravel, sand and clay-gravel mixture foundation soil type. Power spectral densities of minaret model obtained by EFDD technique, and stabilization diagrams of minaret model attained by the SSI technique, were determined for all three different foundation soil types. The first three modal frequencies, mode shapes, and modal damping ratios of the minaret model were evaluated. The power spectral densities of gravel, sand and clay-gravel mixture foundation types are shown for the EFDD technique in Figure 6, Figure 9, and Figure 12 , respectively. Furthermore, the stabilization diagram of the gravel, sand and clay-gravel mixture foundation types is shown in Figure 7, Figure 10 and Figure 13, respectively. Also, the mode shapes of the minaret model for gravel, sand and clay-gravel mixture foundation types obtained by EFDD and SSI techniques are presented in Figure 8, Figure 11 and Figure 14, respectively. Natural frequencies, modal damping ratios and mode shapes of the minaret model are identified by means of the ambient vibration test in three different foundation soil types. First three natural frequencies obtained by both EFDD and SSI techniques are presented in Table 1. Moreover, Modal damping ratios of the minaret model are shown in Table 2 for both techniques.

The OMA results show that the first three natural frequencies of the minaret model are in the range of $20-100 \mathrm{~Hz}$. It can also be seen from the analyses that the foundation soil type has a considerable effect on natural frequencies of the minaret model. While the lowest natural frequencies of the minaret model are exhibited in case of the sand foundation soil type, the highest natural frequencies are observed in case of the clay-gravel mixture foundation soil type. For all cases, it can be seen that the first two natural frequencies are relatively close to each other. However, the third natural frequencies of gravel and clay-gravel mixture foundation soil and sand foundation soil types are approximately 4.5 and 3 times bigger than the first two natural frequencies of the minaret model, respectively. This may be due to high rigidity of the scaled minaret model.

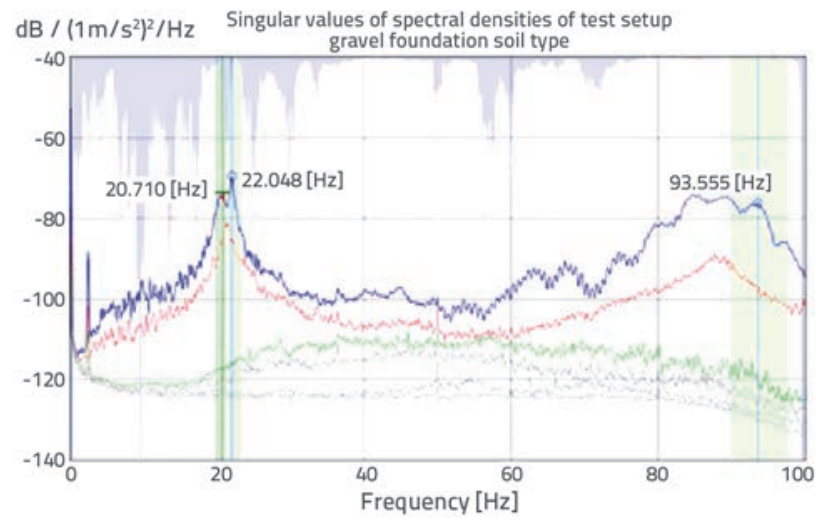

Figure 6. Power spectral density of gravel foundation soil type of minaret model obtained using EFFD technique

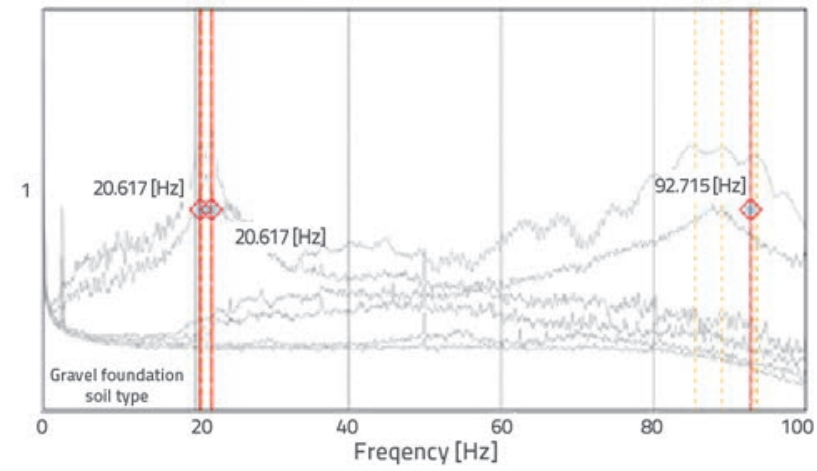

Figure 7. Stabilization diagram of gravel foundation soil type of minaret model obtained using SSI technique

Additionally, natural frequencies of each foundation types obtained by the EFDD technique are nearly the same as those
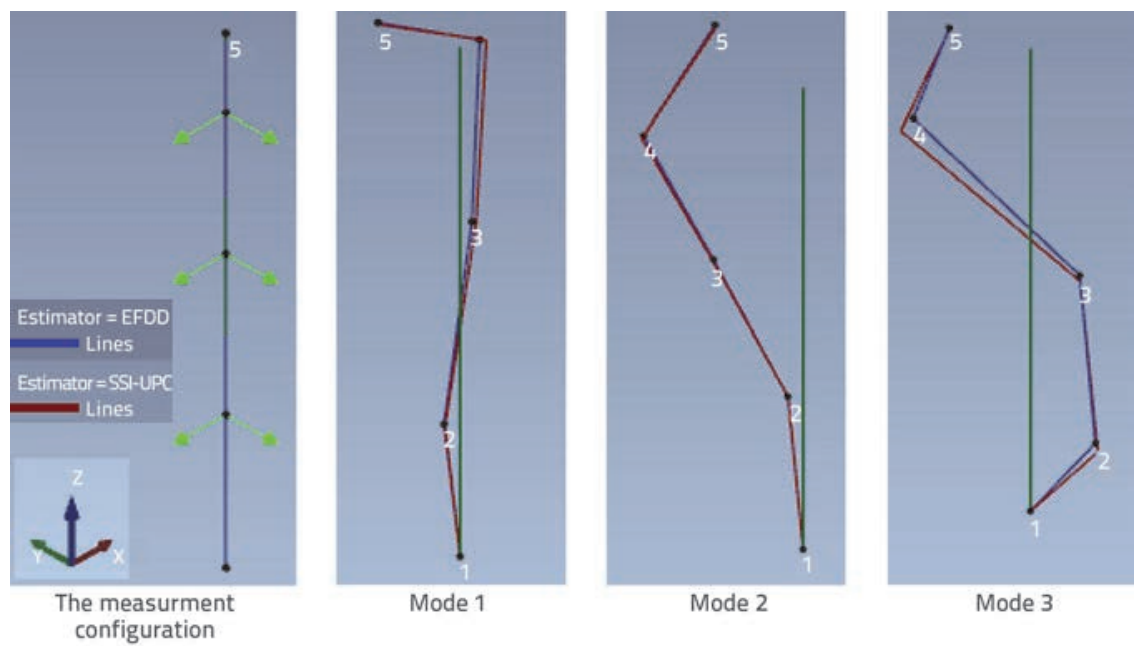

Figure 8. Mode shapes for gravel foundation soil type of minaret model 


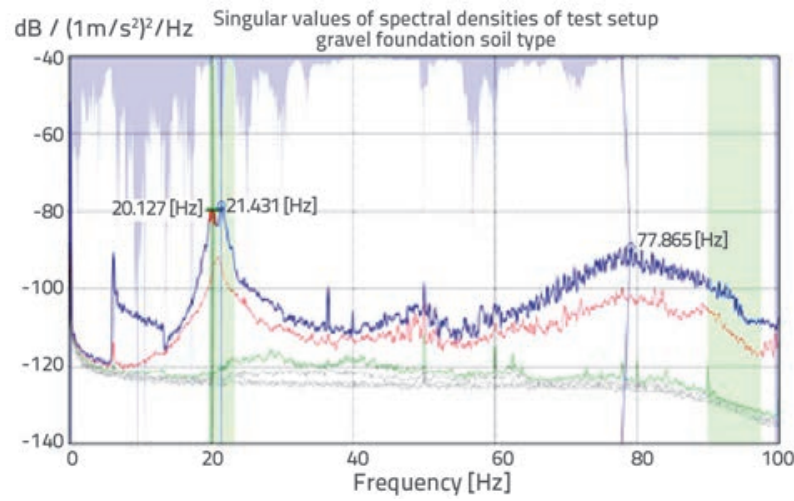

Figure 9. Power spectral density of sand foundation soil type of minaret model obtained using EFFD technique

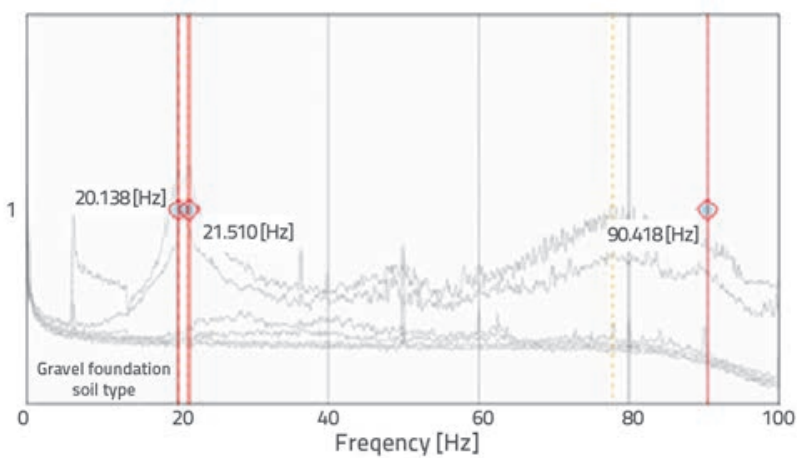

Figure 10. Stabilization diagram of sand foundation soil type of minaret model obtained using SSI technique
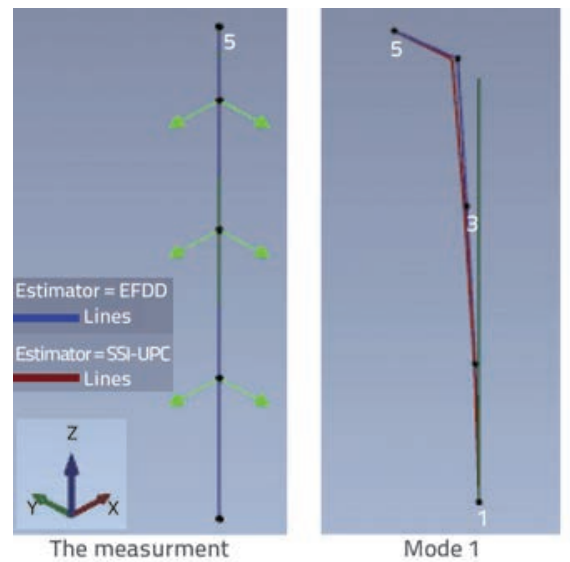

Mode 1

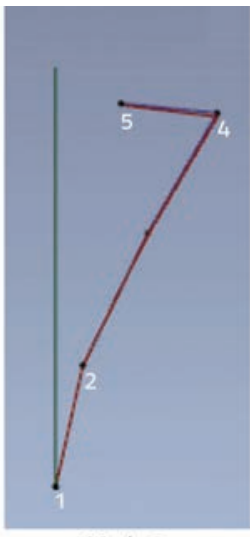

Mode 2

Figure 11. Mode shapes for sand foundation soil type of minaret mode

attained by the SSI technique. This corroboration of frequencies can also be seen at the mode shapes of minaret model for EFDD and SSI techniques. It is considered that the experimental tests were performed successfully due to good harmony of mode shapes of both techniques. On the other hand, the first three mode shapes of foundations soil types have some discrepancy between each other. Furthermore, it can be observed from

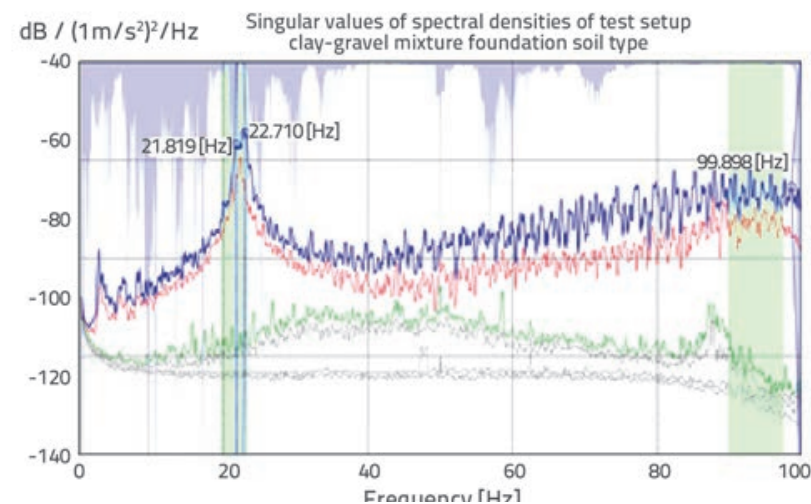

Figure 12. Power spectral density of clay-gravel mixture foundation soil type of minaret model obtained using EFFD technique

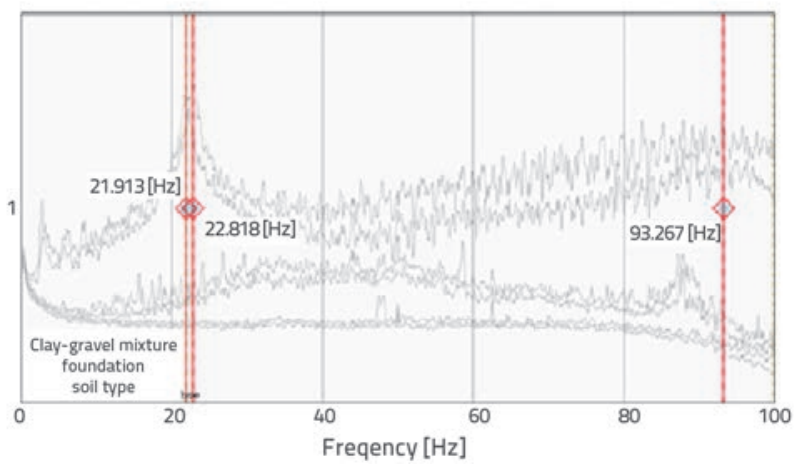

Figure 13. Stabilization diagram of clay-gravel mixture foundation soil type of minaret model obtained using SSI technique

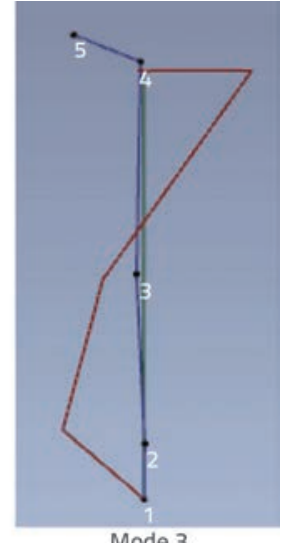

Mode 3 the mode shapes that the main modal behaviours of the minaret model are bending and vertical movement.

As mentioned before, damping ratios of structures are significantly affected by the soil-structure interaction. It can clearly be seen that the modal damping ratios of the minaret model vary randomly according to the foundation soil type. Therefore, it is hard to come to a complete agreement for damping ratios of the minaret model. It can be said that the first three modal damping ratios of the minaret model computed by means of the SSI technique are bigger than those obtained using the EFDD technique. Mean values of the damping ratios of the structure might be used for all three selected foundation soil types. For the EFDD technique, the averages of the gravel, sand and clay-gravel mixture foundation soil types are $1.25 \%, 1.22 \%$ and 1.185 , respectively. According to the SSI technique, those values are $2.35 \%, 1.76 \%$ and $2.631 \%$, respectively. It can also be seen that the biggest modal damping ratio is obtained for the gravel foundation soil type. 


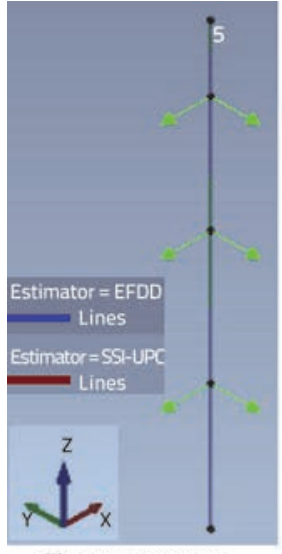

The measurment configuration

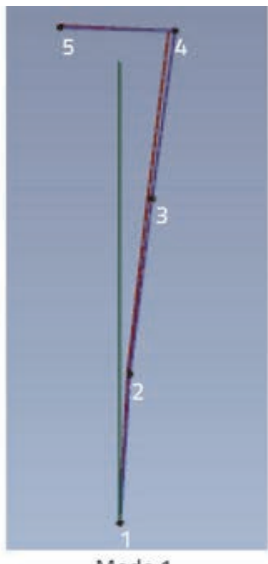

Mode 1

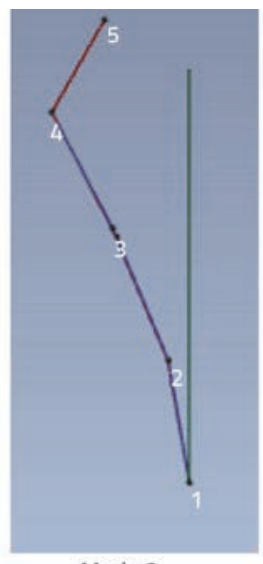

Mode 2

Figure 14. Modeshapes for clay-gravel mixture foundation soil type of minaret model

The experimental analyses results were also validated by considering MAC between the natural modes obtained by EFDD

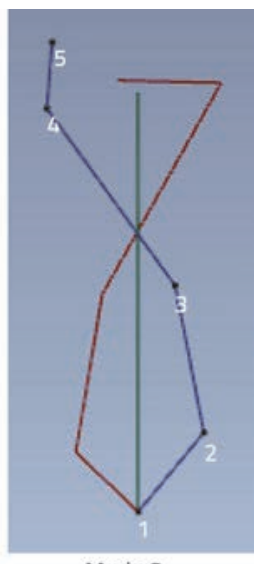

Mode 3 and SSI techniques. The MAC matrix form between EFDD and SSI techniques for all three foundation soil types are presented in Figure 14. It can be observed that, in general, mode shapes attained for both EFDD and SSI techniques exhibit a fairly good correlation between first three natural mode shapes of the minaret model. Also, the MAC values are tabulated in Table 3 .

The diagonals of MAC matrices illustrate that the estimated mode shapes of both EFDD and SSI techniques are almost the same. It was also revealed that no missing or extra modes develop in both techniques. Only the third mode of the sand and clay-gravel mixture shows lower MAC values. More accurate values of these modes could be obtained by using more sensors.

Table 1. First three natural frequencies of minaret model

\begin{tabular}{|c|c|c|c|c|c|c|}
\hline \multirow{2}{*}{ Mode } & \multicolumn{4}{|c|}{ Natural frequencie [Hz] } & \multicolumn{2}{c|}{$\begin{array}{c}\text { Clay-gravel mixture } \\
\text { foundation soil }\end{array}$} \\
\cline { 2 - 7 } & \multicolumn{2}{|c|}{ Gravel foundation soil } & \multicolumn{2}{|c|}{ Sand foundation soil } & SSI & \multicolumn{2}{c|}{ EFDD } & SSI \\
\cline { 2 - 7 } & EFDD & SSI & EFDD & 21.819 & 21.913 \\
\hline 1 & 20.710 & 20.617 & 20.127 & 21.510 & 99.898 & 22.818 \\
\hline 2 & 22.048 & 20.617 & 21.431 & 90.418 & & 93.267 \\
\hline
\end{tabular}

Table 2. First three modal damping ratios of minaret model

\begin{tabular}{|c|c|c|c|c|c|c|}
\hline \multirow{2}{*}{ Mode } & \multicolumn{4}{|c|}{ Modal damping ratios [\%] } & \multicolumn{2}{c|}{$\begin{array}{c}\text { Clay-gravel mixture } \\
\text { foundation soil }\end{array}$} \\
\cline { 2 - 7 } & \multicolumn{2}{|c|}{ Gravel foundation soil } & \multicolumn{2}{c|}{ Sand foundation soil } & SSI & \multicolumn{2}{c|}{ EFDD } & SSI \\
\cline { 2 - 7 } & EFDD & SSI & EFDD & 1.259 & 1.179 & 1.875 \\
\hline 1 & 1.352 & 1.037 & 1.064 & 1.151 & 0.781 & 1.558 \\
\hline 2 & 1.149 & 1.278 & 1.412 & 2.883 & 1.595 & 4.460 \\
\hline
\end{tabular}

Table 3. MAC values between EFDD and SSI for all tree cases

\begin{tabular}{|c|c|c|c|c|c|c|c|c|c|c|}
\hline \multirow{3}{*}{$\begin{array}{l}\text { 닌 } \\
\text { gूँ } \\
\text { 은 }\end{array}$} & \multirow{3}{*}{ Mode } & \multicolumn{3}{|c|}{ Gravel foundation soil } & \multicolumn{3}{|c|}{ Sand foundation soil } & \multicolumn{3}{|c|}{$\begin{array}{l}\text { Clay-gravel mixture } \\
\text { foundation soil }\end{array}$} \\
\hline & & \multicolumn{3}{|c|}{ EFDD } & \multicolumn{3}{|c|}{ EFDD } & \multicolumn{3}{|c|}{ EFDD } \\
\hline & & 1 & 2 & 3 & 1 & 2 & 3 & 1 & 2 & 3 \\
\hline \multirow{3}{*}{ SSI } & 1 & 0.993 & 0.049 & 0.119 & 0.994 & 0.080 & 0.295 & 0.998 & 0.044 & 0.128 \\
\hline & 2 & 0.051 & 0.996 & 0.244 & 0.081 & 0.989 & 0.044 & 0.030 & 0.999 & 0.342 \\
\hline & 3 & 0.125 & 0.279 & 0.911 & 0.062 & 0.094 & 0.415 & 0.174 & 0.003 & 0.054 \\
\hline
\end{tabular}



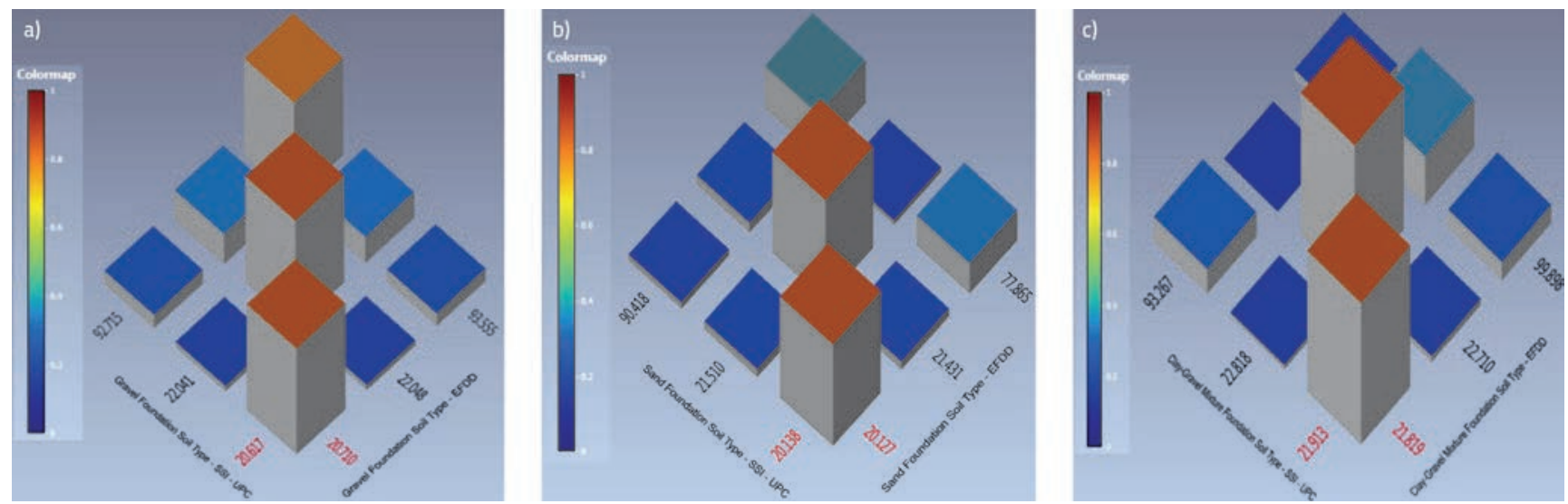

Figure 15. MAC values between EFDD and SSI for all three cases: a) gravel foundation soil type; b) sand foundation soil type; c) clay-gravel mixture foundation soil type

\section{Conclusion}

This study focuses on the effects of different foundation soil types on the dynamic behaviour of reinforced concrete minarets. For this purpose, a 1:20 reduced scale reinforced concrete minaret was constructed in laboratory conditions. The reinforced minaret model was embedded into gravel, sand and clay-gravel mixture foundation soil types on the site. Experimental measurements were carried out by the OMA under ambient vibrations such as wind and vehicle loads, and experimental dynamics characteristics of the minaret model (natural frequencies, mode shapes and modal damping ratios) were determined by using the EFFD based on frequency domain and the SSI based on time domain techniques.

Natural frequencies of the reinforced minaret model alter depending on the foundation soil types. The first three natural frequencies obtained are in the range of $20-100 \mathrm{~Hz}$. Maximum natural frequencies were observed in the clay-gravel mixture foundation soil type. However, the minimum natural frequencies of the minaret model were established in the sand foundation soil type. Also, the first three modal damping ratios vary between $0.781-1.595 \%$ and $1.151-4.460 \%$ for EFDD and SSI techniques, respectively. The highest values of the modal damping ratio were obtained for the gravel foundation soil type for the first two natural modes. On the other hand, the claygravel mixture foundation soil type exhibited the biggest modal damping ratios if compared to the gravel and sand foundation soil types. As a result of the decomposition of signals according to the EFDD and SSI techniques, almost similar dynamic characteristics of the reinforced concrete minaret model were obtained for each foundation soil type. These cases show that the EFDD and SSI techniques are in good agreement with each other for the experimental work.

The operational modal analyses results apparently demonstrate that different foundation soil types have important effects on dynamic characteristics of reinforced minaret structures. In conclusion, it can be stated that the Operational Modal Analysis based on the ambient vibration test can be used safely in order to determine the influence of different foundation soil types on dynamic characteristics of reinforced concrete minarets especially in earthquake regions.

\section{Acknowledgment}

This research was supported under the State Planning Organization Infrastructure Project, 2011, "Central Laboratory of Materials and Structures" by the Ondokuz Mayıs University (Research No: 2011BȘV1134).

\section{REFERENCES}

[1] Fukuwa, N., Ghannad, M.A.: Soil-Stucture Interaction Effect on the Eigenproperties of Structure, in: Elev. World Conf. Earthq. Eng., 949 (1996)

[2] Tașkın, B., Özdemir, P., Özel, N.M.: Evaluation of Orta-Çankiri June 06, Earthquake, Paper no: AT-130 [in Turkish], in: Proceedings Fifth Natl. Conf. Earthq. Eng., Istanbul, Turkey, pp. 1-11, 2003.

[3] Dogangün, A.: Performance of reinforced concrete buildings during the May 1, 2003 Bingöl Earthquake in Turkey, Eng. Struct., 26 (2004), pp. 841-856. https://doi.org/10.1016/j. engstruct.2004.02.005.

[4] Aydan, Ö., Ulusay, R., Kumsar, H.: Site Investigation and Engineering Evaluation of the Van Earthquakes of October $23^{\text {rd }}$ November $9^{\text {th }}$, 2011, Turkish Earthq. Found., 2013 (2012).

[5] Dogangün, A., Sezen, H., Tuluk, O.i., Livaoğlu, R., Acar,R.: Traditional Turkish Masonry Monumental Structures and their Earthquake Response, Int. J. Archit. Herit., 1 (2007) 251, https:// doi.org/10.1080/15583050701436980.

[6] Akcay, H., Türkay, S.: Identification of power spectra by reweighted and regularized nuclear norm minimization, Control Conf. (ASCC), $10^{\text {th }}$ Asian. (2015). https://doi.org/10.1109/ASCC.2015.7244396 
[7] Lin, C.C., Wang, J.F., Ueng, J.M.: Vibratıon Control Identification of Seismically Excited m.d.o.f. Structure-PTMD Systems, Journal of Sound and Vibration, 240 (2001), pp. 87-115

[8] Jacobsen, N.J., Andersen, P., Brincker, R.: Using Enhanced Frequency Domain Decomposition as a Robust Technique to Harmonic Excitation in Operational Modal Analysis, Proc. ISMA2006 Int. Conf. Noise Vib. Eng., pp. 3129-3140, 2006.

[9] Mack, D.R., Gardner-Morsee, G.: Modal Identification of CableStayed Pedestrian Bridge, J. Struct. Eng. 119 (1994), pp. 33843404.

[10] Jar-Nan, J., Pappa, R.S.: An eigensystem realization algorithm for modal parameter identification and model reduction, J. Guid. Control. Dyn., 8 (1985), pp. 620-627.

[11] Van Overschee, P., De Moor, B.: Subspace identification for linear system: Theory - implementation - applications, 1996, https://doi. org/10.1109/IEMBS.2008.4650193.

[12] Bayraktar, A., Altunișik, A.C., Sevim, B.B., Türker, T., Can Altunisik, A.: Modal Testing, Finite-Element Model Updating, and Dynamic Analysis of an Arch Type Steel Footbridge, J. Perform. Constr. Facil., 23 (2009), pp. 81-89. https://doi.org/10.1061/(ASCE)08873828(2009)23:2(81).

[13] Ivanovic, S., Pavic, A., Reynolds, P.: Finite element modelling and updating of a lively footbridge: The complete process, J. Sound Vib., 301 (2007) , pp. 126-145. https://doi.org/10.1016/j. jsv.2006.09.024.

[14] Brownjohn, J.M.W.: Vibration charcteristics of a suspension footbridge, J. Sound Vib., 202 (1997), pp. 29-46. https://doi. org/10.1006/jsvi.1996.0789.

[15] Brownjohn,1992, Ambient vibration survey of Fatih Sultan Mehmet Bridges.pdf, (n.d.).

[16] Siringoringo, D.M., Fujino, Y.: System identification of suspension bridge from ambient vibration response, Eng. Struct., 30 (2008), pp. 462-477. https://doi.org/10.1016/j.engstruct.2007.03.004.

[17] Ben, J., Papán, D.: Dynamic Modeling and Testing of Cable - Stayed Pedestrian Bridge, Proc. $14^{\text {th }}$ Int. Modal Anal. Conf., 4 (2011), pp. 4-6.

[18] Abdel-Gaffar, A.M., Scott, R.F., Craign, M.J.: Full scale experimental investigation of a modern earth dam, 1980.

[19] Ventura, C.E., Lord, J.F., Simpson, R.D.: Effective use of ambent vibration measurements for modal updating of a 48 storey building in Vancouver, Canada, in: Int. Conf., Structural Dyn. Model. Anal. Correl. Valid., 2002.

[20] Srinivas, V., Sasmal, S., Ramanjaneyulu, K., Jeyasehar, C.A.: Influence of test conditions on modal characteristics of reinforced concrete structures under different damage scenarios, Arch. Civ. Mech. Eng., 13 (2013), pp. 491-505. https://doi.org/10.1016/j. acme.2013.04.006.

[21] Zdravkovic, S., Zlatkov, D., Mladenovic, B., Igic, T., Stojic, N.: A bearing structure and finished construction behaviour analysis based on the full-scale experimental research, Facta Univ. - Ser. Archit. Civ. Eng., 8 (2010), pp. 119-127. https://doi.org/10.2298/ FUACE1001119Z.

[22] Ivanovic, S.S., Trifunac, M.D.: Ambient vibration surveys of full-scale structures using personal computers: examples for Kaprielian Hall BT, 1995.

[23] Dooms, D., Degrande, G., De Roeck, G., Reynders, E.: Finite element modelling of a silo based on experimental modal analysis, Eng. Struct., 28 (2006), pp. 532-542. https://doi.org/10.1016/j. engstruct.2005.09.008
[24] Luz, E., Gurr-Beyer, C., Stöcklin, W.: Experimental investigation of natural frequencies and modes of the HDR nuclear power plant by means of microtremor excitation, in: $8^{\text {th }}$ WCEE, San Fr., pp. 977, 1984.

[25] Gentile, C., Saisi, A.: Ambient vibration testing of historic masonry towers for structural identification and damage assessment, Constr. Build. Mater., 21 (2007), pp. 1311-1321. https://doi. org/10.1016/j.conbuildmat.2006.01.007.

[26] Diaferio, M., Foti, D., Giannoccaro, N.I.: Ambient vibration testing and operational modal analysis of a historic tower, 1952.

[27] Sezen, H., Acar, R., Dogangun, A., Livaoglu, R.: Dynamic analysis and seismic performance of reinforced concrete minarets, Eng. Struct., 30 (2008), pp. 2253-2264. https://doi.org/10.1016/j. engstruct.2007.11.005.

[28] Yi, T.H., Li, H.N., Sun, H.M.: Multi-stage structural damage diagnosis method based on "energy-damage" theory, Smart Struct. Syst., 12 (2013), pp. 345-361.

[29] Dogangun, A., Acar, R., Sezen, H., Livaoglu, R.: Investigation of dynamic response of masonry minaret structures, Bull. Earthq. Eng., 6 (2008), pp. 505-517. https://doi.org/10.1007/s10518008-9066-5.

[30] Yi, T.H., Li, H.N., Zhao, X.Y.: Noise smoothing for structural vibration test signals using an improved wavelet thresholding technique, Sensors (Switzerland)., 12 (2012), pp. 11205-11220. https://doi. org/10.3390/s120811205.

[31] Modal of style concrete for identification, Dynamic Testing of Civil Engineering Structures Series, Exp. Tech., pp. 65-75, 2009, https:// doi.org/10.1111/j.1747-1567.2009.00400.x.

[32] Bayraktar, A., Sevim, B., Altunișik, A.C., Türker, T.: Earthquake analysis of reinorced concrete minarets using ambient vibration test results, Struct. Des. Tall Spec. Build., 19 (2010), pp. 257-273. https://doi.org/10.1002/tal.464.

[33] Türker, T.: Ambient vibration test of building base slab for different ground conditions, Meas. J. Int. Meas. Confed., 52 (2014), pp. 7784. https://doi.org/10.1016/j.measurement.2014.03.007.

[34] Stewart, J.P., Fenves, G.L.: System identification for evaluating soil-structure interaction effects in buildings from strong motion recordings, Earthq. Eng. Struct. Dyn., 27 (1998), pp. 869-885. https://doi.org/10.1002/(SICI)10969845(199808)27:8<869::AID-EQE762>3.0.CO;2-9.

[35] Nist, Soil-Structure Interaction for Building Structures, GCR 12917-21, prepared by the NEHRP Consultants Joint Venture, a partnership of the Applied Technology Council and the Consortium for Universities for Research in Earthquake Engineering, for the National Institute of Standards and Technology, Gaithersburg, MD, 2012.

[36] Brincker, R., Zhang, L., Andersen, P.: Modal identification from ambient response using frequency domain decomposition, Proc. SPIE - Int. Soc. Opt. Eng., 1 (2000).

[37] Gade, S., Møller, N.B., Herlufsen, H., Konstantin-Hansen,H., Anderson, P.: Frequency Domain Techniques for Operational Modal Analysis, Proc. 1 $1^{\text {st }}$ IOMAC Conf., (2005) 11.

[38] Bendat, J.S., Piersol, A.G.: Random Data: Analysis and Measurement Procedures. Wiley, New York, 1986.

[39] Hermans, L., Der Aueveraer, V.: Modal testing and analysis of structures under operational conditions: Industrial applications., Mech. Syst. Syetem Process., 13 (1999), pp. 193-216.

[40] Peeters, B.: System identification and damage detection in civil engineering, KU Leuven, 2000. 
[41] Reynders, E., De Roeck, G.: Reference-based combined deterministic-stochastic subspace identification for experimental and operational modal analysis, Mech. Syst. Signal Process., 22 (2008), pp. 617-637. https://doi.org/10.1016/j. ymssp.2007.09.004.

[42] Swanson Analysis System, SVS, ARTEMIS 1.5, (2011).

[43] Yu, D.J., Ren, W.X.: EMD-based stochastic subspace identification of structures from operational vibration measurements, Eng Struct., 27 (2005), pp. 1741-1751. https://doi.org/10.1016/j. engstruct.2005.04.016
[44] Pastor, M., Binda, M., Harčarik, T.: Modal assurance criterion, Procedia Eng., 48 (2012), pp. 543-548. https://doi.org/10.1016/j. proeng.2012.09.551.

[45] TS EN 206-1, Turkish Standard, Concrete - Specification, performance, production and Conformity, 2014.

[46] Ventura, C.E., Lord, J.F., Simpson, R.D.: Effective Use of Ambient Vibration Measurements for Modal Updating of a 48 Storey Building in Vancouver, Canada, Int. Conf. "Structural Dyn. Model. Anal. Correl. Valid., pp. 1-10, 2002. 